\title{
AMINO-ACID CONTENT OF SERUM IN RHEUMATOID ARTHRITIS
}

\author{
BY \\ ERIK NETTELBLADT AND BRITT-MARIE SANDELL \\ From the Medical Department III and the Central Clinical Laboratory, Södersjukhuset, Stockholm, Sweden
}

In an earlier investigation (Hammarsten, Jonsson, Lindgren, Neri, Nettelbladt, Plum, and Sandell, 1960), it was found that an amino-acid mixture had a stimulating effect upon erythropoiesis in the in vitro cultivation of bone marrow. This effect was more pronounced on bone marrow from cases of rheumatoid arthritis than on marrow from patients with other diseases. A possible interpretation of this result is that there is a lack of free amino acids in serum from cases of rheumatoid arthritis.

On the basis of this finding, a study was undertaken of the amino-acid content of the serum in cases of rheumatoid arthritis, and to this end methods have been devised which permit the determination of seventeen different amino acids with relatively satisfactory reliability.

\section{Methods}

Serum was first deproteinized by passage on a cation column (Zeokarb $225 \mathrm{H}^{+}, 4 \cdot 5 \mathrm{NC}$ ). Inorganic salts and proteins passed the column, and the amino acids were eluted from the column with concentrated ammonia. The ammonia solution was evaporated to dryness and the residue, containing the amino acids, was dissolved again in a known amount of 10 per cent. isopropyl alcohol in water. An aliquot of the isopropylalcohol solution corresponding to $0.5 \mathrm{ml}$. serum was then separated with the help of two-dimensional paper chromatography. The solvents used in the first direction were methanol, pyridine, and water $(80: 4: 20)$, and in the second direction tert. butanol, diethylamine, methyl ethylketone, and water (33:4:40:27) according to the method of Redfield (1953). After drying, the papers were stained with 0.4 per cent. solution of ninhydrin in acetone containing 5 per cent. acetic acid. The spots obtained were then cut out and eluted in $5 \mathrm{ml} .60$ per cent. ethyl alcohol, and the colour was read in a spectrophotometer at $570 \mathrm{~m} \mu$. The result was evaluated by comparison with standard solutions which were treated as test samples and run in the same chromatographic vessel.
A test of the method is presented in Table I, where the results of five analyses are compared with the weighed amount. Furthermore, the experiments were performed

TABLE I

RECOVERY OF AMINO ACIDS AFTER PASSAGE ON FIVE DIFFERENT ZEOKARB COLUMNS

\begin{tabular}{|c|c|c|c|c|}
\hline \multirow{2}{*}{$\underset{\text { Acid }}{\text { Amino }}$} & \multicolumn{2}{|c|}{ Values Obtained } & \multirow{2}{*}{$\begin{array}{l}\text { Percentage } \\
\text { Recovery }\end{array}$} & \multirow{2}{*}{$\begin{array}{l}\text { Weighed } \\
\text { Quantity }\end{array}$} \\
\hline & $\begin{array}{l}5 \text { ml. solution } \\
\text { Mean } \pm \text { S.E. }\end{array}$ & $\begin{array}{l}2 \text { ml. solution } \\
\text { Mean } \pm \text { S.E. }\end{array}$ & & \\
\hline Alanine & $8 \cdot 78 \quad 0 \cdot 15$ & $3 \cdot 24 \quad 0 \cdot 18$ & $\begin{array}{l}99 \\
91\end{array}$ & $\begin{array}{l}8 \cdot 9 \\
3 \cdot 56\end{array}$ \\
\hline Arginine & $10 \cdot 00 \quad 1.09$ & $2.90 \quad 0.20$ & $\begin{array}{l}57 \\
42\end{array}$ & $\begin{array}{r}17 \cdot 42 \\
6 \cdot 89\end{array}$ \\
\hline Aspartic Acid & $12 \cdot 56 \quad 0 \cdot 74$ & $\begin{array}{ll}3.90 & 0.58\end{array}$ & $\begin{array}{l}94 \\
73\end{array}$ & $\begin{array}{r}13 \cdot 31 \\
5 \cdot 34\end{array}$ \\
\hline Glutamic Acid & $14 \cdot 82 \quad 0 \cdot 60$ & $\begin{array}{ll}5 \cdot 72 & 0 \cdot 14\end{array}$ & $\begin{array}{r}101 \\
98\end{array}$ & $\begin{array}{r}14 \cdot 71 \\
5 \cdot 88\end{array}$ \\
\hline Glutamine & $12 \cdot 78 \quad 0.55$ & $\begin{array}{ll}5 \cdot 28 & 0.29\end{array}$ & $\begin{array}{l}88 \\
90\end{array}$ & $\begin{array}{r}14 \cdot 60 \\
5 \cdot 85\end{array}$ \\
\hline Glycine & $8 \cdot 26 \quad 0 \cdot 32$ & $3.95 \quad 0.32$ & $\begin{array}{l}110 \\
132\end{array}$ & $\begin{array}{l}7 \cdot 51 \\
3 \cdot 00\end{array}$ \\
\hline Histidine & $9.54 \quad 0.37$ & $4 \cdot 00 \quad 0 \cdot 10$ & $\begin{array}{l}62 \\
65\end{array}$ & $\begin{array}{r}15 \cdot 50 \\
6 \cdot 20\end{array}$ \\
\hline Leucine & $13 \cdot 30 \quad 0 \cdot 19$ & $4.46 \quad 0.53$ & $\begin{array}{r}101 \\
85\end{array}$ & $\begin{array}{r}13 \cdot 17 \\
5 \cdot 27\end{array}$ \\
\hline Lysine. . & $11.44 \quad 0.48$ & $4 \cdot 14 \quad 0 \cdot 22$ & $\begin{array}{l}78 \\
71 \\
\end{array}$ & $\begin{array}{r}14 \cdot 62 \\
5 \cdot 86 \\
\end{array}$ \\
\hline Methionine .. & $14 \cdot 54 \quad 0.55$ & $4 \cdot 74 \quad 0 \cdot 26$ & $\begin{array}{l}97 \\
96 \\
\end{array}$ & $\begin{array}{r}14 \cdot 92 \\
4 \cdot 92 \\
\end{array}$ \\
\hline Phenylalanine & $\begin{array}{ll}15 \cdot 62 & 0.28\end{array}$ & $5.96 \quad 0.42$ & $\begin{array}{l}95 \\
90 \\
\end{array}$ & $\begin{array}{r}16 \cdot 50 \\
6 \cdot 60 \\
\end{array}$ \\
\hline Serine... & $10 \cdot 30 \quad 0.17$ & $4 \cdot 00 \quad 0 \cdot 14$ & $\begin{array}{l}98 \\
95\end{array}$ & $\begin{array}{r}10 \cdot 51 \\
4 \cdot 21\end{array}$ \\
\hline Threonine & $11.06 \quad 0.20$ & $3 \cdot 82 \quad 0 \cdot 14$ & $\begin{array}{l}93 \\
80 \\
\end{array}$ & $\begin{array}{r}11 \cdot 90 \\
4 \cdot 77 \\
\end{array}$ \\
\hline Tryptophan & $17.84 \quad 0.89$ & $6 \cdot 32 \quad 0 \cdot 10$ & $\begin{array}{l}87 \\
77\end{array}$ & $\begin{array}{r}20 \cdot 40 \\
8 \cdot 17 \\
\end{array}$ \\
\hline Tyrosine & $15 \cdot 50 \quad 0.59$ & $6.93 \quad 0.17$ & $\begin{array}{l}86 \\
96\end{array}$ & $\begin{array}{r}18 \cdot 12 \\
7 \cdot 25 \\
\end{array}$ \\
\hline Valine & $12 \cdot 76 \quad 0.20$ & $4 \cdot 66 \quad 0 \cdot 14$ & $\begin{array}{r}109 \\
99\end{array}$ & $\begin{array}{r}11 \cdot 72 \\
4 \cdot 70\end{array}$ \\
\hline
\end{tabular}


with two concentrations of amino acid standards, and the loss with reference to the concentration was then studied. The loss on the columns was very marked for the following amino acids: arginine, histidine, and lysine. The amount recovered, on the other hand, seemed to be proportional to the concentration, with the possible exception of arginine and aspartic acid, which at a lower concentration gave a lower percentage recovery.

As regards methionine, it was observed that after passage on the column this amino acid divided on irregular spot came in this connexion to coincide with the glycine spot. As the concentration of methionine is normally very small, the value for the glycine concentration in serum will not be essentially changed thereby. No correction of the glycine values for methionine was therefore made.

The proline concentration was determined by a special method. When the amino acids had been dissolved in 10 per cent. isopropyl alcohol as described above, onedimensional paper chromatograms were developed in propanol : water $(7: 3)$ for 8 hours according to the method of Boissonnas (1950). When these strips of paper had dried they were stained with 0.4 per cent. isatin in acetone, washed with $1 \mathrm{n} \mathrm{HCl}$ according to the method of Pasieka and Morgan (1956), and then evaluated with a Spinco Analytrol Densitometer.

$$
\text { The variance } \frac{\text { S.D. } \times 100}{M} \text { was } 15 \text { per cent. }
$$

\section{Material}

All the cases examined were fasting when the blood sample was taken, but there was no standardization of diet before the analyses. Serum was used for the analyses, which were started on the same day as the samples were taken. Normal sera from subjectively healthy persons belonging to the hospital staff were used as controls. The erythrocyte sedimentation rate, haemoglobin, serum glutamic oxalacetic transaminase (S-GOT), and protein electrophoresis were normal and the urine was free from glucose and protein.

All the cases of rheumatoid arthritis used in this study fulfilled the criteria for classical rheumatoid arthritis of the American Rheumatism Association (Ropes, Bennett, Cobb, Jacox, and Jessar, 1959). subsequent paper chromatography into two spots. The

\section{Results}

Table II shows the serum concentration of seventeen different free amino acids in normal persons. When the material was divided according to sex, no difference was observed, and total values are therefore given in the Tables.

TABLE II

SERUM CONTENT OF FREE AMINO ACIDS IN NORMAL SUBJECTS

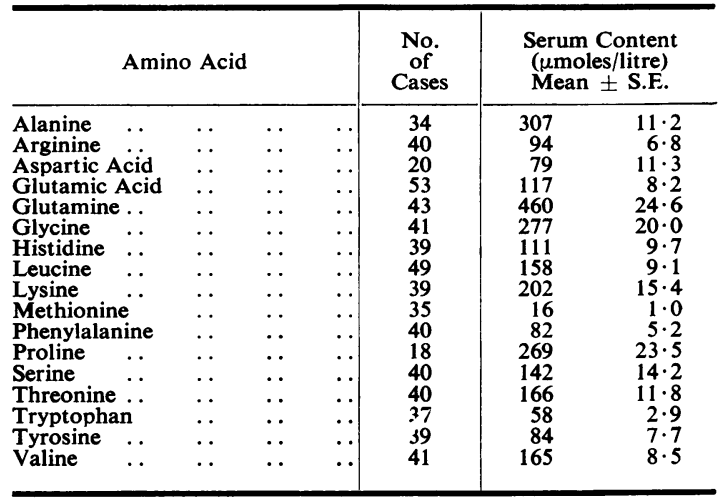

Table III (opposite) shows the serum concentration of free amino acids in cases of rheumatoid arthritis. For some of the amino acids statistically significant differences from normal could be demonstrated (Table IV). The concentration of glutamic acid is above normal in rheumatoid arthritis, whereas glutamine is lower than normal. The ratio glutamic acid : glutamine in serum was calculated for each individual case and comparisons were made between the mean ratios of the groups, with the following results:

Rheumatoid arthritis $=0 \cdot 60$; Normal $=0 \cdot 20$;

Difference $=0 \cdot 40 ; t=5 \cdot 71 ; \mathrm{P}<0.001$.

In order to study the specificity of these findings, investigations were carried out on sixteen cases with different internal medical diseases (including pneu-

TABLE IV

SERUM CONTENT OF THE FIVE FREE AMINO ACIDS WHICH SHOWED A STATISTICALLY SIGNIFICANT DIFFERENCE BETWEEN RHEUMATOID ARTHRITIS AND NORMAL SERA

\begin{tabular}{|c|c|c|c|c|c|c|c|c|c|c|c|}
\hline \multirow{2}{*}{\multicolumn{3}{|c|}{ Amino Acid }} & \multicolumn{3}{|c|}{ Rheumatoid Arthritis } & \multicolumn{3}{|c|}{ Normal Subjects } & \multirow{3}{*}{$\begin{array}{l}\text { Difference } \\
\begin{array}{l} \\
+126 \\
-198 \\
-55 \\
-31\end{array}\end{array}$} & \multirow{3}{*}{$\begin{array}{c}t \\
2 \cdot 55 \\
3 \cdot 02 \\
5 \cdot 13 \\
4 \cdot 37 \\
3 \cdot 34\end{array}$} & \multirow{2}{*}{$\mathbf{P}$} \\
\hline & & & \multirow{2}{*}{$\begin{array}{c}\begin{array}{c}\text { No. of } \\
\text { Cases }\end{array} \\
17 \\
16 \\
17 \\
16 \\
16\end{array}$} & \multicolumn{2}{|c|}{$\begin{array}{l}\text { umoles/litre } \\
\text { Mean } \pm \text { S.E. }\end{array}$} & \multirow{2}{*}{$\begin{array}{c}\begin{array}{c}\text { No. of } \\
\text { Cases }\end{array} \\
40 \\
53 \\
43 \\
39 \\
39\end{array}$} & \multicolumn{2}{|c|}{$\begin{array}{l}\text { umoles/litre } \\
\text { Mean } \pm \text { S.E. }\end{array}$} & & & \\
\hline $\begin{array}{l}\text { Arginine } \\
\text { Glutamic Acid : } \\
\text { Glutamine } \\
\text { Histidine } \\
\text { Tyrosine }\end{array}$ & $\begin{array}{l}\cdots \\
\cdots \\
\cdots \\
\cdots\end{array}$ & \begin{tabular}{l|}
$\ldots$ \\
$\cdots$ \\
$\cdots$ \\
$\cdots$
\end{tabular} & & $\begin{array}{r}67 \\
243 \\
262 \\
56 \\
53\end{array}$ & $\begin{array}{r}7 \cdot 7 \\
40 \cdot 9 \\
29 \cdot 1 \\
8 \cdot 0 \\
4 \cdot 6\end{array}$ & & $\begin{array}{r}94 \\
117 \\
460 \\
111 \\
64\end{array}$ & $\begin{array}{r}6 \cdot 8 \\
8 \cdot 2 \\
24 \cdot 6 \\
9 \cdot 7 \\
7 \cdot 7\end{array}$ & & & $\begin{array}{l}<0.05 \\
<0.01 \\
<0.001 \\
<0.001 \\
<0.01\end{array}$ \\
\hline
\end{tabular}


TABLE III

SERUM CONTENT OF FREE AMINO ACIDS IN CASES OF RHEUMATOID ARTHRITIS

\begin{tabular}{|c|c|c|c|c|c|c|}
\hline \multicolumn{4}{|c|}{ Amino Acid } & \multirow[b]{2}{*}{$\begin{array}{c}\begin{array}{c}\text { No } \\
\text { of } \\
\text { Cases }\end{array} \\
17 \\
17 \\
16 \\
16 \\
17 \\
17 \\
16 \\
16 \\
17 \\
15 \\
15 \\
57 \\
16 \\
14 \\
17 \\
16 \\
16\end{array}$} & \multicolumn{2}{|c|}{$\begin{array}{l}\text { Serum Content } \\
\text { ( } \mu \text { moles/litre) } \\
\text { Mean } \pm \text { S.E. }\end{array}$} \\
\hline 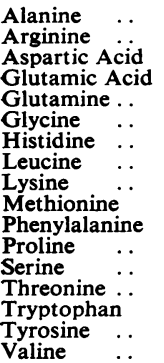 & $\begin{array}{l}\ldots \\
\ldots \\
\cdots \\
\cdots \\
\cdots \\
\cdots \\
\cdots \\
\cdots \\
\cdots \\
\cdots \\
\cdots \\
\cdots\end{array}$ & $\begin{array}{l}\cdots \\
\cdots \\
\cdots \\
\cdots \\
\cdots \\
\cdots \\
\cdots \\
\cdots \\
\cdots \\
\cdots \\
\cdots \\
\cdots \\
\cdots\end{array}$ & $\begin{array}{l}\cdots \\
\cdots \\
\cdots \\
\cdots \\
\cdots \\
\cdots \\
\cdots \\
\cdots \\
\cdots \\
\cdots \\
\cdots \\
\cdots \\
\ldots\end{array}$ & & $\begin{array}{r}344 \\
67 \\
98 \\
243 \\
262 \\
278 \\
56 \\
151 \\
227 \\
21 \\
115 \\
209 \\
155 \\
148 \\
46 \\
53 \\
171\end{array}$ & $\begin{array}{r}19 \cdot 1 \\
7 \cdot 7 \\
18 \cdot 2 \\
40 \cdot 9 \\
29 \cdot 1 \\
20 \cdot 1 \\
8 \cdot 0 \\
10 \cdot 1 \\
20 \cdot 1 \\
4 \cdot 2 \\
16 \cdot 6 \\
13 \cdot 9 \\
10 \cdot 8 \\
26 \cdot 9 \\
6 \cdot 0 \\
4 \cdot 6 \\
13 \cdot 0\end{array}$ \\
\hline
\end{tabular}

monia, cardiosclerosis, hypertonia, nephritis, and anaemia). The results were within normal limits, except for the tyrosine concentration, which showed a subnormal value $(55 \pm 6 \cdot 5)$ similar to that observed in the rheumatoid arthritis group $(53 \pm 4 \cdot 6)$.

\section{Discussion}

Several writers, including Trnavská and Sitaj (1960) and more recently Armstrong, Bocking, and Derrick (1962), have shown that the total amount of free amino acids in plasma or serum in cases of rheumatoid arthritis is lower than normal. In the present investigation the total amount of free amino acids was low, but there was no significant difference noted between the arthritic and normal cases. As regards the individual free amino acids, low values were recorded for arginine, glutamine, tyrosine, and histidine, while the concentration of glutamic acid was higher in cases of rheumatoid arthritis than in normal subjects. Using microbiological methods, Brodie, Wallraff, Borden, Holbrook, Stephens, Hill, Kent, and Kemmerer (1950) found low concentrations of arginine, histidine, and threonine in the serum of patients with rheumatoid arthritis. Trnavská and Sitaj (1960) found a significant reduction of proline and histidine, while arginine and threonine were normal. We found low values of proline in the rheumatoid arthritis group, but the difference was not statistically significant:

Rheumatoid arthritis $\mathbf{M}=209 \pm 13 \cdot 9$; Normal $M=269 \pm 23 \cdot 5$.

To ascertain whether the deviation in the serum concentration of free amino acids is specific for rheumatoid arthritis, we also analysed a series of cases of other internal medical diseases. The choice of such control material is very difficult, but the cases chosen showed the same general characteristics with respect to chronicity and nutrition, as the cases of rheumatoid arthritis.

Our controls gave the same serum concentrations of individual free amino acids as had been found in the normal subjects, with the exception of tyrosine. Any differences found between the normal group and the rheumatoid arthritis group were not due to medical treatment, as all therapy was discontinued during the taking of the samples, and none of the patients was treated with cortisone or ACTH, which affect the amino-acid metabolism (Derrick and Hanley, 1957). It therefore seems probable that the differences found for arginine, glutamine, histidine and glutamic acid are due to rheumatoid arthritis.

On the other hand, this series showed no correlation between the serum amino-acid levels and pathological activity, chronicity, or duration of disease. Nor was it possible to observe any correlation between the amino-acid changes and the serum concentration of gamma-globulins, alpha globulins, or C-reactive protein. It may well be, however, that the methodological error is too large for such correlations to be detected.

The glutamic acid : glutamine ratio was considerably higher in the cases of rheumatoid arthritis than in the normal subjects. This may be because the formation of amide from glutamic acid is prevented, for according to Elliott (1953) this formation is dependent on adenosine triphosphate (ATP). Györki and Sandell (1959) found that the ATP content of erythrocytes in cases of rheumatoid arthritis was different from normal. The high glutamic acid : glutamine ratio in rheumatoid arthritis might also be explained by enzymatic disturbances.

The tryptophan metabolism has also been shown to be disturbed in cases of rheumatoid arthritis (Bett, 1962), but we obtained a slightly lower serum concentration of free tryptophan in our cases of rheumatoid arthritis, and the difference was not statistically significant.

It seems doubtful whether the low serum levels of certain free amino acids observed by us are related to the clinical symptoms, since large amounts of amino acids have been supplied to patients with rheumatoid arthritis without affecting the pathological activity, anaemia, or reticulocytes. It seems likely that the deviations from normal observed by us demonstrate changes in the amino-acid and protein metabolism in cases of rheumatoid arthritis. 


\section{Summary}

The serum concentration of free amino acids has been investigated by paper chromatography in a series of cases of rheumatoid arthritis. Low concentrations of arginine, glutamine, tyrosine, and histidine were found in rheumatoid arthritis, while the glutamic acid levels were higher than normal. The significance of these findings is briefly discussed.

We gratefully record our appreciation to Dr. Greta Hammarsten for many suggestions and continued encouragement.

\section{REFERENCES}

Armstrong, J. J. B., Bocking, D., and Derrick, J. B. (1962). Arthr. and Rheum., 5, 635.

Bett, I. M. (1962). Ann. rheum. Dis., 21, 63.

Boissonnas, R. A. (1950). Helv. chim. Acta, 33, 1966.

Brodie, E. C., Wallraff, E. B., Borden, A. L., Holbrook, W. P., Stephens, C. A. L., Hill, D. F., Kent, L. J., and Kemmerer, A. R. (1950). Proc. Soc. exp. Biol. (N.Y.), 75, 285.

Derrick, J. B., and Hanley, A. P. (1957). Canad. J. Biochem. Physiol., 35, 1005.

Elliott, W. H. (1953). J. biol. Chem., 201, 661.

Györki, J., and Sandell, B. M. (1959). Nord. Med., $62,1788$.

Hammarsten, G., Jonsson, E., Lindgren, G., Neri, A., Nettelbladt, E., Plum, C. M., and Sandell, B.-M. (1960). Acta rheum. scand., 6, 81.
Pasieka, A. E. and Morgan, J. F. (1956)l Proc. Soc. exp. Biol. (N.Y.), $93,54$.

Redfield, R. R. (1953). Biochim. biophys. Acta, 10, 344.

Ropes, M. W., Bennett, G. A., Cobb, S., Jacox, R., and Jessar, R. A. (1959). Ann. rheum. Dis., 18, 49.

Trnavská, Z., and Sitaj, S. (1960). Z. Rheumaforsch., 19, 125.

La teneur du sérum en amino-acides dans

l'arthrite rhumatismale

RÉSUMÉ

On détermina le taux sérique des amino-acides libres au moyen de la chromatographie sur papier dans une série de cas d'arthrite rhumatismale. Ce taux fut bas pour l'arginine, la glutamine, la tyrosine et l'histidine, tandis que celui de l'acide glutamique s'éléva au dessus de la normale. On discute ici brièvement l'importance de ces résultats.

\section{Contenido sérico de amino-ácidos en la artritis reumatoide}

\section{SUMARIO}

Se determinó la concentración sérica de aminoácidos libres por la cromatografía sobre papel en una serie de casos de artritis reumatoide. Esta concentración fué baja con respecto a la arginina, glutamina, tirosina e histidina, mientras que la del ácido glutámico fué superior a lo normal. El significado de estos hallazgos se discute brevemente. 